\title{
De rentecurve voor de waardering van langetermijngaranties op de Solvency II-balans
}

Paul van Ammelrooij

\begin{abstract}
SAMENVATTING Vanaf 2016 geldt een nieuw toezichtskader voor verzekeraars opererend binnen de Europese Unie, genaamd Solvency II. In dit toezichtskader staan marktwaarden en risico's centraal, waardoor meer kapitaal aangehouden moet worden voor risicovolle producten en minder voor minder risicovolle producten. In dit artikel wordt inzichtelijk gemaakt waarom de gekozen verantwoordingswijze voor langetermijngaranties resulteert in een volatiel eigen vermogen op de Solvency II-balans over de tijd. Hieruit blijkt dat de volatiliteit met name veroorzaakt wordt doordat de gebruikte rentecurve voor de waardering van langetermijngaranties afwijkt van de rentecurve voor de waardering van activa. Er is sprake van een zogenaamde "valuation mismatch". Tevens beschrijft dit artikel in hoeverre een dergelijke volatiliteit te rechtvaardigen is vanuit het bedrijfsmodel van verzekeraars en welke maatregelen de Europese gemeenschap heeft betrokken in het toezichtskader ter verkleining van de valuation mismatch.
\end{abstract}

RELEVANTIE VOOR DE PRAKTIJK Accountants, controllers en andere financieel professionals werkzaam in de verzekeringsindustrie zullen geconfronteerd worden met een nieuw toezichtskader dat gaat gelden voor verzekeraars binnen de Europese Unie. De solvabiliteitsvereisten van dit kader zijn complexer en meer gebaseerd op recente actuariële en risicomanagementtechnieken. Financiële professionals zullen de stap moeten maken om deze cijfers beter te doorgronden. Dit artikel draagt daaraan bij door de problematiek rondom langetermijngaranties vanuit een balansperspectief inzichtelijk te maken.

\section{Inleiding}

Vanaf het begin van deze eeuw is de Europese Gemeenschap (EG) bezig met de ontwikkeling van een nieuw toezichtskader voor verzekeraars opererend binnen de Europese Unie (EU). De huidige toezichtregels binnen de EU, genaamd Solvency I, dateren respectievelijk uit 1973 voor schadeverzekeraars (EEG, 1973, Richtlijn 73/239/EEG) en uit 1979 voor levensverzekeraars (EEG, 1979, Richtlijn 79/267/EEG). Deze toezichtre- gels voldoen niet meer aan de huidige vereisten met betrekking tot risicomanagement en de bescherming van polishouders. Om een wijziging van het toezichtskader te bewerkstelligen heeft de EG een nieuwe Europese richtlijn aangenomen betreffende de toegang tot uitoefening van het verzekerings- en het herverzekeringsbedrijf binnen de EU, genaamd Solvency II (EG, 2009, Richtlijn 2009/138/EG). Deze nieuwe richtlijn bevat uitsluitend de algemene voorschriften en principes van het toezichtskader. Uitgangspunt is dat marktwaarden en risico's centraal staan bij de bepaling van de solvabiliteitscijfers, waardoor meer kapitaal aangehouden moet worden voor risicovolle producten en minder voor minder risicovolle producten. Meer gedetailleerde voorschriften moeten worden gedefinieerd in nadere besluiten hieromtrent.

De algemene doelstelling van de EG was om dit toezichtskader in september 2012 in te voeren, maar dit is niet gerealiseerd. De EG bleek onder andere niet in staat overeenstemming te bereiken omtrent de te gebruiken rentecurve voor de verantwoording van langetermijngaranties op de Solvency II-balans, zoals annuiteiten ten behoeve van de oudedagsvoorziening. De solvabiliteitscijfers van dergelijke producten zijn in het voorgestelde toezichtskader ${ }^{1}$ volatiel over de tijd, omdat alle veranderingen in de economische omgeving tot uiting komen in de solvabiliteitscijfers. De mate waarin een verzekeraar gevoelig is voor de economische veranderingen wordt hierbij niet betrokken. Deze gevoeligheid is in het bijzonder inzichtelijk geworden tijdens de kredietcrisis en de daarop volgende Eurocrisis. Dit artikel geeft een beschrijving van deze problematiek vanuit een balansperspectief.

De kernvraag van dit artikel luidt:

Waarom resulteert de gekozen rentecurve voor de waardering van langetermijngaranties op de Solvency II-balans in een volatiel eigen vermogen over de tijd? En in hoeverre is ditte rechtvaardigen vanuit het bedrijfsmodel van verzekeraars? 
Tevens wordt in dit artikel uiteengezet wat de mogelijke consequenties van het nieuwe toezichtskader zijn voor de gevoerde producten in de verzekeringsmarkt en voor de financiering van verzekeraars. Ten slotte worden de maatregelen betreffende de rentecurve ter verkleining van de volatiliteit beschreven die de EG heeft betrokken in het aangepaste toezichtskader (EG, 2013). De door de verzekeraars afgegeven garanties kunnen voor specifieke producten over een lange termijn van kracht zijn. Het langetermijnkarakter is één van de redenen voor de complexe solvabiliteitsregels voor verzekeraars. Het is immers lastig vast te stellen of een verzekeraar voldoende middelen heeft om zijn langetermijngaranties te waarborgen. Deze garanties kunnen immers nog tientallen jaren van kracht zijn. De EG heeft als lastige opdracht om voor dergelijke verzekeringsproducten een Europees toezichtskader te ontwikkelen, dat tevens rekening houdt met de verschillende producten die per land gevoerd worden. Om de problematiek betreffende de verantwoording van langetermijngaranties te doorgronden is enige basiskennis van het Solvency II-raamwerk van belang. Daarom wordt in paragraaf 2 de essentie van het Solvency II-toezichtskader uiteengezet, waarbij met name de structuur van het toezichtkader en de basis ter bepaling van de solvabiliteitscijfers centraal staan. Vervolgens adresseren de latere paragrafen de problematiek rondom langetermijngaranties, d.w.z. de gebruikte rentecurve. Paragraaf 3 maakt inzichtelijk waarom de solvabiliteitscijfers van verzekeraars met langetermijngaranties volatiel zijn onder de Solvency II-voorschriften. In paragraaf 4 wordt vervolgens beschreven hoe economische veranderingen de financiële positie van verzekeraars beïnvloeden. Ofwel, is de volatiliteit te rechtvaardigen? Tevens worden de door de EG genomen maatregelen met betrekking tot de verantwoording van langetermijngaranties beschreven in deze paragraaf (EG, 2013, art.77). Deze maatregelen reduceren de volatiliteit. In paragraaf 5 wordt een reflectie gegeven op de gekozen maatregelen, en ten slotte bevat paragraaf 6 een overzicht van de belangrijkste conclusies.

\section{Introductie Solvency II}

Een toezichtskader voor verzekeraars dient twee belangrijke kerntaken te vervullen. Ten eerste het garanderen van de stabiliteit van het financiële systeem (de macro-economische kerntaak) en ten tweede de bescherming van de polishouders van de verzekeraar (de micro-economische kerntaak). Deze kerntaken worden onder Solvency II vervuld door een systeem waar marktwaarden en risico's centraal staan. De doelstelling van dit systeem betreft het geven van de juiste prikkels ten behoeve van risicomanagement. Concreet betekent dit dat een verzekeraar meer kapitaal moet aanhouden voor risicovolle producten en minder voor minder risicovolle producten. In het huidige solvabili-

\section{Tabel 1 Solvency II-Marktwaardebalans. Staats- en ondernemings- obligaties betrokken op de balans, omdat verzekeraars in de praktijk veelvuldig in obligaties investeren ter dekking van hun langetermijngaranties.}

\begin{tabular}{|l|c|l|c|}
\hline \multicolumn{2}{|c|}{ Activa } & \multicolumn{2}{c|}{ Passiva } \\
\hline Staatsobligaties & A & Eigen vermogen & C \\
\hline Ondernemingsobligaties & B & Verzekeringsverplichtingen & D \\
\hline Balanstotaal & A+B & Balanstotaal & C+D \\
\hline
\end{tabular}

teitsraamwerk (Solvency I) is dat niet het geval; in dit raamwerk wordt het aan te houden risicokapitaal immers vastgesteld aan de hand van vaste percentages ten opzichte van de reserve. Het risicoprofiel van de producten speelt nauwelijks een rol. Een verzekeraar kan daardoor additionele garanties verstrekken aan zijn polishouders zonder daar extra risicokapitaal voor te moeten aanhouden. Solvency II tracht deze perverse prikkel te elimineren uit het solvabiliteitsraamwerk door het centraal stellen van marktwaarden en risico's. De marktwaarden komen tot uiting in een zogenaamde marktwaardebalans. Een marktwaardebalans is een balans waarbij de activa en passiva van een onderneming verantwoord worden tegen reële waarde (tabel 1). Alhoewel Solvency II spreekt over een marktwaardebalans, worden in feite reële waarden bedoeld. De reële waarde is een proxy voor de marktverkoopprijs waarbij de invulling afhankelijk is van het al dan niet aanwezig zijn van een actieve markt waarop officiële noteringen tot stand komen. Indien er sprake is van een dergelijke markt dan is de reële waarde gelijk aan de marktwaarde. Ontbreekt een dergelijke markt, dan zijn andere benaderingen noodzakelijk om tot een reële waarde te komen (Krens, 2003; IASB, 2011). Dit betekent dat kostprijswaarderingen niet op deze balans voorkomen.

Het eigen vermogen van deze balans is echter nog geen proxy voor de aandeelhouderswaarde van de verzekeraar en wel om een tweetal redenen. Ten eerste worden niet alle activa en passiva betrokken op de marktwaardebalans, bijvoorbeeld de waarde van het merk van de verzekeringsfranchise. Ten tweede is de waardering van verzekeringsverplichtingen in een zekere mate subjectief van aard. Marktwaarden zijn objectief vast te stellen in het geval van financiële instrumenten die op de beurs worden verhandeld. Een blik in de financiële bijlage van de krant geeft vaak voldoende informatie. In het geval van verzekeringsverplichtingen kan dit echter niet. Verzekeringsverplichtingen worden niet ter beurze verhandeld en daardoor is er geen prijs beschikbaar in een actieve en voldoende liquide markt. De reele waarde dient daardoor te worden vastgesteld aan de hand van een waarderingsmodel waarbij de gebruikte rekenrente één van de belangrijkste aannames is. 
Figuur 1 Value at Risk concept Solvency II. Het eigen vermogen van de verzekeraar betreft het gemiddelde van de verdeling en is gelijk aan $\mathbf{4 0}$ euro. Het rood gearceerde gebied specificeert het 0,5\%-betrouwbaarheidsinterval. De grens van het betrouwbaarheidsinterval specificeert de omvang van het vrij vermogen van de verzekeraar en bedraagt in dit geval 18 euro (nietgebonden kapitaal). De kapitaalvereisten zijn gelijk aan het eigen vermogen minus het vrij eigen vermogen, ofwel 22 euro.

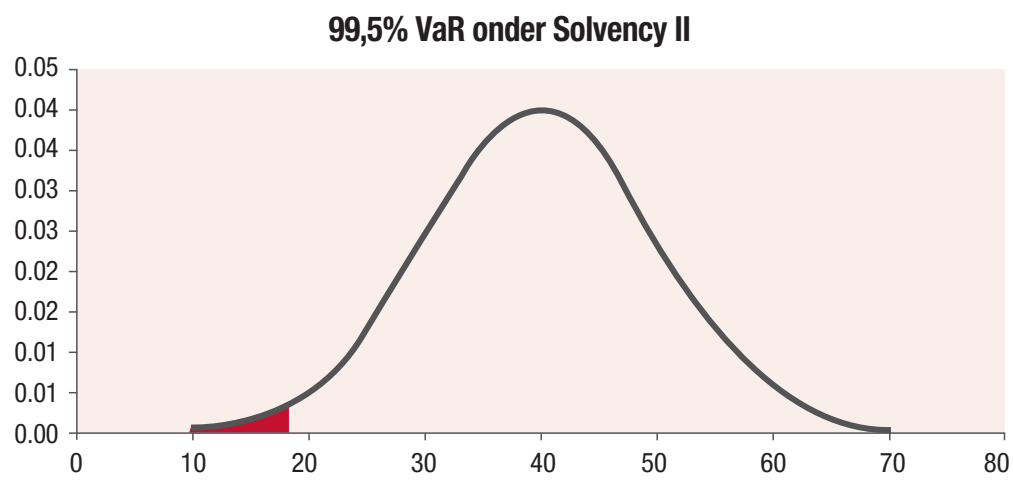

Het eigen vermogen is onderdeel van de marktwaardebalans. Om vast te stellen of de verzekeraar over voldoende middelen beschikt dient het eigen vermogen te worden geconfronteerd met de kapitaalvereisten. De gebruikte risicomaatstaf om de kapitaalvereisten vast te stellen is de eenjaars-Value at Risk (VaR). De eenjaars-VaR voor een verzekeraar kan worden gedefinieerd als het maximale economische verlies voor een verzekeraar binnen één jaar met 99,5\% zekerheid (figuur 1). Dit betekent dat een verzekeraar voldoende middelen ter beschikking moet hebben om het maximaal mogelijke verlies binnen één jaar op te kunnen vangen. Dit maximaal mogelijke verlies kan enerzijds worden vastgesteld conform een standaardmodel (eenvoudige formule) of anderzijds conform een door de toezichthouder goedgekeurd Intern model. Hierbij moet tevens worden aangetoond dat het gebruikte risicomodel wordt gebruikt voor de sturing van de verzekeraar (use test). Grote verzekeraars sturen hun bedrijfsvoering voornamelijk op basis van intern ontwikkelde mo-

Figuur 2 Grafische weergave van Solvency II-raamwerk

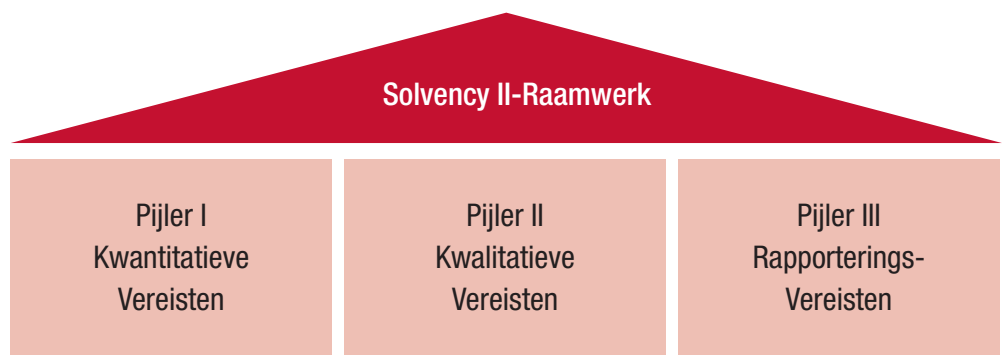

dellen, zodat de sturing aansluit op de in de portefeuille gelopen risico's. Deze verzekeraars zullen naar verwachting goedkeuring voor de toepassing van hun interne modellen aanvragen bij hun toezichthouders.

Het vorenstaande betekent dat Solvency II de overdraagbaarheid van portefeuilles centraal stelt. Immers, als het maximaal mogelijke verlies zich voordoet bij een verzekeraar dan is de economische waarde van de onderneming nog steeds positief en kan de verzekeringsportefeuille zonder verlies overgedragen worden aan een andere verzekeraar. In hoeverre dit uitgangspunt realistisch is, kan in twijfel getrokken worden. Ten eerste hebben de kredietcrisis en daarop volgende Eurocrisis aangetoond dat deze theorie niet opgaat bij een algeheel falen van een systeem. Alle verzekeraars hebben dan tegelijkertijd te maken met economische tegenwind en ondervinden identieke problemen. Ten tweede is de waarde van een onderneming of portefeuille afwijkend in het geval deze niet verkocht wordt onder normale marktomstandigheden. Andere verzekeraars zullen niet bereid zijn om de reële waarde te betalen in het geval een portefeuille onder druk van de toezichthouder verkocht moet worden. Er vindt een afslag plaats, waardoor de reele waarde significant lager uitvalt dan de indirecte opbrengstwaarde. Het is daarom ook de vraag of de reële waarde het beste uitgangspunt is voor een solvabiliteitsraamwerk van verzekeraars. Met andere woorden, is Solvency II wel gebaseerd op het juiste waardebegrip? Naar mijn mening staat het langetermijnverdienmodel voor een breed scala aan verzekeringsproducten haaks op de waardering tegen reële waarde.

Tot op heden zijn uitsluitend de kwantitatieve vereisten van het Solvency II-raamwerk ter sprake gekomen, terwijl het beheersen van de bedrijfsvoering en de daaraan gekoppelde risico's niet exclusief over kwantitatieve maatstaven gaat. Het is tevens van belang dat het bestuur en het toezicht gedegen zijn ingericht bij een verzekeraar (Pijler II) en dat stakeholders een gedegen inzicht verschaft wordt in de solvabiliteitspositie (Pijler III). Het Solvency II-raamwerk bevat daarom drie pijlers (figuur 2).

De eerste pijler bevat de kwantitatieve vereisten waaraan een verzekeraar moet voldoen. Het specificeert bijvoorbeeld dat alle activa en passiva op marktwaarde moeten worden gewaardeerd en dat de solvabiliteitsvereisten conform een eenjaars-VaR worden bepaald. Deze zijn reeds de revue gepasseerd. De tweede pijler bevat de meer kwalitatieve vereisten van het raamwerk, ofwel de vereisten van goed bestuur en goed toezicht. Zo schrijft deze pijler bijvoorbeeld een periodiek uitgevoerde Own Risk and Solvency Assessment (ORSA) voor alsmede de minimale vereisten met betrekking tot de inrichting van de organisatie. Van iedere verzekeraar wordt verwacht dat zij de volgende functies hebben ingericht: (1) de risicomanagementfunctie, (2) de 
actuariële functie, (3) de interne-accountantsfunctie, en (4) de compliancefunctie (voldoen aan wet- en regelgeving). Ten slotte maakt de derde pijler de cirkel rond. Deze pijler specifieert de vereisten met betrekking tot externe verantwoording aan de toezichthouder alsmede andere stakeholders omtrent de solvabiliteit van de verzekeraar.

Deze paragraaf heeft een meer algemeen overzicht van het Solvency II-raamwerk gegeven. De volgende paragraaf gaat dieper in op de kwantitatieve solvabiliteitsvereisten (Pijler 1) en de problematiek rondom de verantwoording van langetermijngaranties op de Solvency II-balans.

\section{Langetermijngaranties onder Solvency II}

In de vorige paragraaf is beschreven wat de belangrijkste bouwstenen zijn van het Solvency II-toezichtskader. In deze paragraaf gaan we nader in op één van deze bouwstenen, namelijk de kwantitatieve solvabiliteitsvereisten van de eerste Solvency II-pijler. Voor wat betreft de kwantitatieve vereisten heeft de EG ervoor gekozen de marktwaarden en risico's centraal te stellen. Dit betekent dat een verzekeraar meer kapitaal op zijn balans moet aanhouden naar gelang er meer risico wordt gelopen en vice versa. Het aan te houden kapitaal is dan in lijn met de gelopen risico's.

Door het ontbreken van een actieve en liquide markt voor verzekeringsverplichtingen zijn complexe waarderingsmodellen noodzakelijk. Het veelgehoorde kritiekpunt op Solvency II is dat er geen adequaat raamwerk is voor langetermijnverzekeringsverplichtingen, en dat de solvabiliteitscijfers van dergelijke producten in het voorgestelde toezichtskader te volatiel zijn in de tijd. Alle veranderingen in de economische omgeving, zoals veranderingen in spreads en rente, zouden tot uiting komen in de solvabiliteitscijfers. Hierbij werd geen rekening gehouden met de mate dat verzekeraars gevoelig zijn voor dergelijke economische veranderingen. Deze gevoeligheid is in het bijzonder inzichtelijk geworden tijdens de kredietcrisis en de daarop volgende Eurocrisis.

In deze paragraaf wil ik de problematiek rondom langetermijngaranties onder Solvency II uiteenzetten aan de hand van een eenvoudig voorbeeld. Dit voorbeeld gaat uit van een balansperspectief. Daarnaast worden de mogelijke oplossingsrichtingen beschreven en de keuzes die de EG hierin maakt.

\section{Voorbeeld}

In tabel 2 is een voorbeeld gegeven van een marktwaardebalans. Op deze balans worden alle activa en passiva verantwoord tegen reële waarde. In het geval van obligaties kan de reële waarde worden herleid van marktwaarden en vervolgens worden uitgedrukt in een effectief rendement (yield) op de obligatie. De reële waarde is dan gelijk aan de verdisconteerde waarde van de verwachte kasstromen tegen het effectief rende-
Tabel 2 Marktwaardebalans op $\mathbf{t}=\mathbf{0}$

\begin{tabular}{|l|c|l|c|}
\hline \multicolumn{2}{|c|}{ Activa } & \multicolumn{2}{c|}{ Passiva } \\
\hline Staatsobligaties & 100 & Eigen vermogen & $?$ \\
\hline Ondernemingsobligaties & 40 & Verzekeringsverplichtingen & $?$ \\
\hline Balanstotaal & 140 & Balanstotaal & 140 \\
\hline
\end{tabular}

Tabel 3 geeft een specificatie van de obligaties betrokken op de marktwaardebalans.

\section{Tabel 3 Specificatie beleggingen op $t=0$ waarbij $M W_{t}=$ Marktwaar- de beleggingen op tijdstip $t, K_{t}=$ Kasstroom op tijdstip $t, y_{t}=$ Effectief rendement op tijdstip $t, s_{t}=$ Spread op tijdstip $t, A_{t, y t}$ $=$ disconteringsfactor van kasstroom op tijdstip t met effec- tief rendement $y_{t}$, risicovrije rente $=4 \%$.}

\begin{tabular}{|l|c|c|l|c|c|}
\hline Beleggingen & $\mathrm{MW}_{0}$ & $\mathrm{KS}_{10}$ & $\mathrm{~A}_{0, \mathrm{y} 0}=\mathrm{MW}_{0} / \mathrm{KS}_{10}$ & $\mathrm{y}_{0}$ & $\mathrm{~S}_{0}$ \\
\hline Italiaanse staatsobligaties & 100 & 148 & $\mathrm{~A}_{10 ; 0,04}=0,676(=100 / 148)$ & $4 \%$ & $0 \%$ \\
\hline Ondernemingsobligaties & 40 & 86 & $\mathrm{~A}_{10 ; 0,08}=0,463(=40 / 86)$ & $8 \%$ & $4 \%$ \\
\hline
\end{tabular}

ment. Het effectief rendement kan worden onderverdeeld in twee componenten zijnde de risicovrije rente en een spread. Hierbij is de spread een indicatie voor het risico van de investering.

De staatsobligaties met een marktwaarde van 100 euro betreffen 10-jaars Italiaanse zero coupon bonds met een kasstroom aan einde jaar 10 van 148 euro. Indien de marktwaarde en de kasstromen bekend zijn kan de disconteringsvoet en daarmee het effectief rendement herleid worden. In dit voorbeeld is het effectief rendement derhalve 4\%. Op identieke wijze kan het effectief rendement op de ondernemingsobligaties afgeleid worden. De ondernemingsobligaties met een marktwaarde van 40 euro betreffen 10 -jaars zero coupon bonds met een kasstroom aan het einde van jaar 10 van 86 euro. Het effectief rendement is dus $8 \%$.

Vervolgens behoeven uitsluitend de verzekeringsverplichtingen nog gewaardeerd te worden. Het kasstroomprofiel van de verzekeringsverplichtingen is identiek aan de Italiaanse staatsobligaties, ofwel één kastroom van 148 euro aan het einde van jaar 10. Dit betekent dat de kasstromen van de verzekeringsverplichtingen volledig overeenkomen met de Italiaanse staatsobligaties. In vaktermen zegt men dat de verzekeringsverplichtingen volledig "cashflow matched" zijn met Italiaanse staatsobligaties. De vraag is dan wat de rekenrente ter waardering van de verzekeringsverplichtingen zou moeten zijn? Aan de ene kant kan beargumenteerd worden dat garanties op basis van het risicovrije rendement gewaardeerd zouden moeten worden (Keller, 2010; Wütrich, 2011). Het woord garantie geeft immers expliciet aan dat er geen risico meer is. Het is 
Tabel 4 Marktwaardebalans op $\mathbf{t}=\mathbf{0}$ bij waardering tegen risicovrije rente

\begin{tabular}{|l|r|l|r|}
\hline \multicolumn{2}{|c|}{ Activa } & \multicolumn{2}{c|}{ Passiva } \\
\hline Staatsobligaties & 100 & Eigen vermogen & 40 \\
\hline Ondernemingsobligaties & 40 & Verzekeringsverplichtingen & 100 \\
\hline Balanstotaal & 140 & Balanstotaal & 140 \\
\hline
\end{tabular}

Figuur 3 Ontwikkeling van 10 jaars rente in eurozone (ECB data)

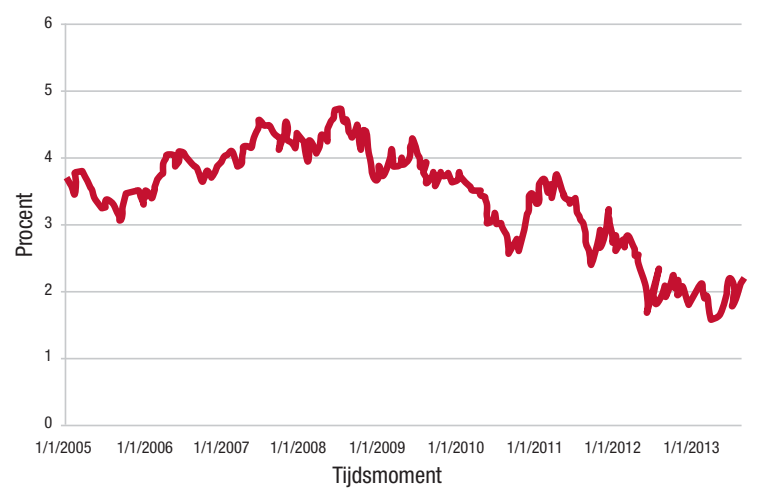

Figuur 4 Ontwikkeling rente op staatsobligaties in de Eurozone (ECB data)

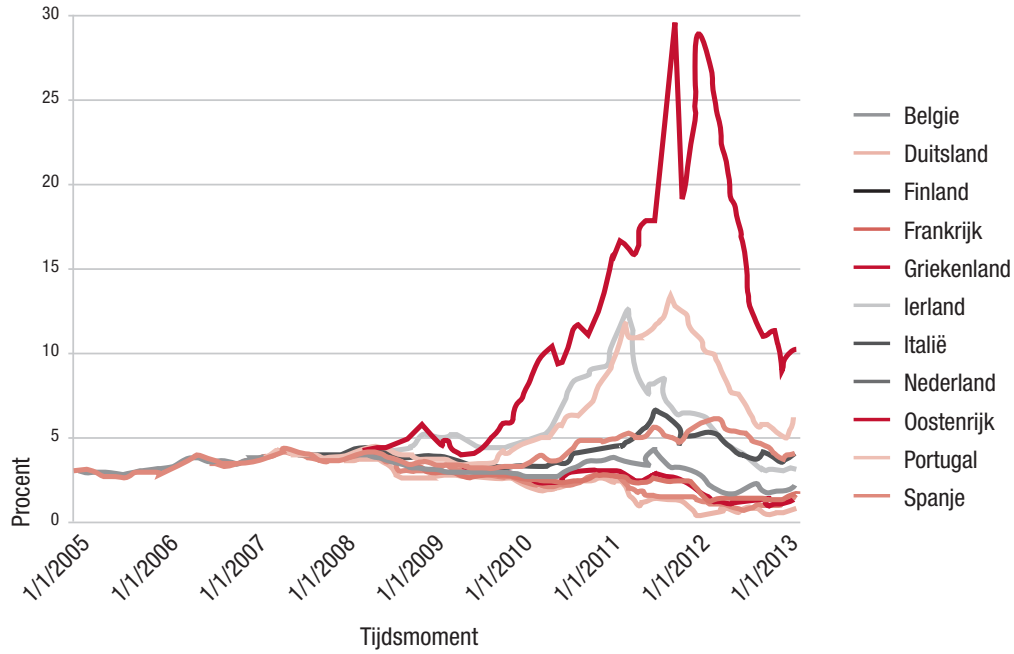

gegarandeerd. Aan de andere kant doet dit wellicht tekort aan het langetermijnkarakter en risicoprofiel van verzekeringsverplichtingen.

Indien we uitgaan van het perspectief dat garanties uitsluitend gewaardeerd dienen te worden tegen de risicovrije rente, dan kunnen verzekeringsverplichtingen relatief eenvoudig gewaardeerd worden. De reële waarde van de verzekeringsverplichtingen kan dan bepaald worden door de verwachte kasstromen uit hoofde van verzekeringsverplichtingen te verdisconteren tegen de risicovrije rente. Aan het begin van 2013 was dit nog de grondslag in het voorgestelde Solvency II-toezichtskader. Alhoewel dit in de praktijk nog niet zo eenvoudig blijkt te zijn. Het Actuarieel Genootschap en Actuarieel Instituut (AG\&AI, 2010, p. 4) hebben een onderzoek uitgevoerd naar de risicovrije rente ter waardering van verzekeringsverplichtingen en concluderen dat "een unieke correcte curve die kan dienen voor de waardering van langlopende verplichtingen niet bestaat in de markt. Er zijn diverse curven beschikbaar die ieder hun voor- en nadelen hebben." In het rapport worden vier alternatieven onderscheiden met ieder een afwijkende curve ter waardering van verzekeringsverplichtingen (AG\&AI, p. 10): (1) swaprente, (2) staatsobligaties, (3) hoogwaardige ondernemingsobligaties en (4) hoogwaardige obligaties met onderpand. De reele waarde van de verzekeringsverplichtingen hangt dus af van de gekozen marktinstrumenten ter bepaling van de risicovrije rente.

In het voorbeeld wordt aangenomen dat de risicovrije rente op tijdstip $t\left(\mathrm{rf}_{\mathrm{t}}\right)$ bekend is en gelijk is aan $4 \%$. De reële waarde van de verzekeringsverplichtingen kan worden vastgesteld door de verwachte toekomstige kasstromen $\left(\mathrm{KS}_{10}=148\right)$ te verdisconteren tegen $4 \%$ $\left(A_{10 ; 0,04}=0,676\right)$ en is derhalve gelijk aan 100 euro. Het eigen vermogen op de marktwaardebalans is dan gelijk aan 40 euro (tabel 4).

De reële waarde van de verzekeringsverplichtingen komt overeen met de staatsobligaties omdat zowel de verwachte kasstromen als het effectief rendement identiek zijn. De waarderingen zouden afwijkend zijn als er een aanzienlijke risico-opslag zou zitten op Italiaanse staatsobligaties, ook wel spread genoemd.

Wat kan het gevolg zijn van het niet betrekken van enige spread bij de waardering van verzekeringsverplichtingen tijdens een crisis? Bijvoorbeeld ten tijde van de Eurocrisis. Deze periode was exceptioneel qua economische ontwikkelingen. In de muntunie daalde de 10 -jaars-rente van de Eurozone van ongeveer $4 \%$ in het begin van 2008 naar ongeveer 3\% in het begin van het 2012 (figuur 3). Dit betekent voor het voorbeeld dat de waarde van de verzekeringsverplichtingen stijgt van 100 euro op $t=0$ naar 110 euro op $t=1$. Een verlies van 10 euro $\left(A_{10 ; 0,03}=0,744\right)$.

De effectieve rendementen op staatsobligaties bewogen echter niet in lijn met de risicovrije rente. De effectieve rendementen op de staatsobligaties toonden namelijk een tweespalt in de muntunie tussen de Noordelijke lidstaten en de Zuidelijke lidstaten. Het effectief rendement op de staatsobligaties van de Zuidelijke lidstaten van de muntunie steeg aanzienlijk, terwijl er een aanzienlijke daling waarneembaar was voor de Noordelijke lidstaten (figuur 4). Het effectief rendement op Italiaanse staatsobligaties steeg van on- 
geveer $4 \%$ in het begin 2008 naar ongeveer 13\% in het begin van het 2012, een stijging van maar liefst $9 \%$. Dit betekent voor het voorbeeld dat de prijs van Italiaanse staatobligaties daalt van 100 euro op $t=0$ naar 44 euro op $\mathrm{t}=1$ (tabel 5). Een verlies van 56 euro.

De impact op de marktwaardebalans is enorm (tabel 6). Het eigen vermogen daalt naar -26 euro doordat de gestegen spread op Italiaanse staatsobligaties op geen enkele wijze wordt gedempt door een waardeverandering van verzekeringsverplichtingen. Integendeel, de waarde van de verzekeringsverplichtingen stijgt door de lagere risicovrije rente. De spread wordt immers niet betrokken in de waardering van de verzekeringsverplichtingen. Er is derhalve sprake van een risicovrije valuation mismatch. op de balans als gevolg van de verschillende waarderingsgrondslagen van activa en passiva, resulterende in een volatiele marktwaardebalans. In dit voorbeeld is het gevolg dat de verzekeraar niet meer over voldoende middelen beschikt ter dekking van haar verplichtingen. Hierbij wil ik opmerken dat dit volatiliteitsprobleem reeds inzichtelijk is gemaakt door Allen en Carletti (2008, p. 358) en dat de impact geringer was geweest als de verzekeraar haar vermogen meer gediversifieerd belegd had.

\section{Nadere beschouwing en de door de EG gekozen oplossingsrichtingen}

De vraag is in hoeverre risicovrije waardering van verzekeringsverplichtingen juist is. Is een verzekeraar wel gevoelig voor alle veranderingen in de economische omgeving? De langetermijnverplichtingen van de verzekeraar hoeven niet direct voldaan te worden en zijn derhalve illiquide ("verplichtingenperspectief"). Met andere woorden, de verzekeraar heeft tijd. Daarnaast is de verzekeraar een investeerder met een langetermijninvesteringshorizon, zij hoeft haar beleggingen niet gedwongen te verkopen en kan wachten op betere tijden ("hold-to-maturity"-perspectief). Zo is bijvoorbeeld het effectief rendement op Italiaanse staatsobligaties aanzienlijk gedaald vanaf 2012 .

Beide perspectieven zijn gebaseerd op de onderverdeling van het effectief rendement. Het effectief rendement bestaat uit twee componenten, zijnde de risicovrije rente en een spread. Deze spread kan vervolgens weer worden onderverdeeld in twee componenten (Hull, 2009, p. 495-498; Barrie+Hibbert, 2009):

1. spread die kan worden toegerekend aan kredietrisico; en

2. spread die kan worden toegerekend aan liquiditeitsrisico.

Het kredietrisico representeert de ongewenste situatie dat een schuldenaar niet meer aan al zijn verplichtingen kan voldoen en dat de schuldeiser niet zijn volledige vordering kan innen. In simpele termen kan kredietrisico gedefinieerd worden als de kans dat een
Tabel 5 Specificatie beleggingen op $\mathrm{t}=1$ waarbij $\mathrm{MW}_{\mathrm{t}}=$ Marktwaarde beleggingen op tijdstip $t, K S_{t}=$ Kasstroom op tijdstip $t, y_{t}=$ Effectief rendement op tijdstip $t, s_{t}=$ Spread op tijdstip $t, A_{t y t}$ $=$ disconteringsfactor van kasstroom op tijdstip t met effectief rendement $y_{t}$, risicovrije rente $=3 \%$.

\begin{tabular}{|l|l|l|l|l|l|}
\hline Beleggingen & $\mathrm{MW}_{1}$ & $\mathrm{KS}_{10}$ & $\mathrm{~A}_{1, \mathrm{y1}}=\mathrm{MW}_{1} / \mathrm{KS}_{10}$ & $\mathrm{y}_{1}$ & $\mathrm{~S}_{1}$ \\
\hline Italiaanse staatsobligaties & 44 & 148 & $\mathrm{~A}_{10 ; 0,13}=0,295(=44 / 148)$ & $13 \%$ & $10 \%$ \\
\hline Ondernemingsobligaties & 40 & 86 & $\mathrm{~A}_{10 ; 0,08}=0,463(=40 / 86)$ & $8 \%$ & $5 \%$ \\
\hline
\end{tabular}

\section{Tabel 6 Marktwaardebalans op $\mathbf{t}=\mathbf{1}$ bij waardering tegen risicovrije rente}

\begin{tabular}{|lc|c|lc|c|}
\hline \multicolumn{2}{|c|}{ Activa } & \multicolumn{2}{c|}{ Passiva } \\
\hline Staatsobligaties & $\downarrow$ & 44 & Eigen vermogen & -26 \\
\hline Ondernemingsobligaties & 40 & Verzekeringsverplichtingen & $\uparrow$ & 110 \\
\hline Balanstotaal & $\mathbf{8 4}$ & Balanstotaal & 84 \\
\hline
\end{tabular}

investeerder zijn geld niet terugkrijgt, zijnde de coupon of de hoofdsom. De overige spread, ook wel illiquiditeitsspread genoemd, heeft voornamelijk betrekking op de mate van liquiditeit en/of sentiment op de markt. Over het algemeen is de illiquiditeitsspread gering in normale economische omstandigheden en substantieel in het geval van een economische crisis, zoals de kredietcrisis en de Eurocrisis.

\subsection{Verplichtingenperspectief}

Het verplichtingenperspectief redeneert vanuit de economische eigenschappen van verzekeringsverplichtingen. Een kenmerk van verzekeringsverplichtingen is dat deze niet worden verhandeld op actieve en liquide markten. Daarnaast zijn de kasstromen van de verzekeringsverplichtingen vaak in hoge mate voorspelbaar, waardoor de economische eigenschappen min of meer gelijk zijn aan die van illiquide obligaties (Keller, 2010). Dit betekent dat de discontering minimaal gelijk zou moeten zijn aan de risicovrije rente plus een premie voor illiquiditeit, de illiquiditeitsspread.

Bijvoorbeeld, neem aan dat de risicovrije rente gelijk is aan $3 \%$ en de spread op hoogwaardige ondernemingsobligaties gelijk is aan $2 \%$. De helft van deze spread heeft betrekking op kredietrisico en de andere helft op liquiditeitsrisico. De illiquiditeitsspread is derhalve gelijk aan $1 \%$. De verzekeringsverplichtingen worden daardoor verdisconteerd tegen een effectief rendement van $4 \%$, zijnde de risicovrije rente van 3\% met daaraan de illiquiditeitsspread van $1 \%$ toegevoegd.

Dit perspectief neemt aan dat verzekeraars minder gevoelig zijn voor kortetermijnvolatiliteit in de spreads op obligaties en wijkt af van het principe dat garanties altijd op basis van het risicovrije rendement gewaardeerd zouden moeten worden. 
Tabel 7 Onderverdeling van spread in twee componenten op $t=1$

\begin{tabular}{|l|c|c|c|}
\hline Beleggingen & Totale Spread & Kredietrisico & Overige spread \\
\hline Italiaanse staatsobligaties & $10,0 \%$ & $2,0 \%{ }^{2}$ & $8,0 \%$ \\
\hline Ondernemingsobligaties & $5,0 \%$ & $1,6 \%$ & $3,4 \%$ \\
\hline Gemiddelde & $7,8 \%$ & $1,8 \%$ & $6,0 \%$ \\
\hline
\end{tabular}

\section{Tabel 8 Marktwaardebalans op $\mathbf{t}=\mathbf{0}$ bij waardering tegen risicovrije} rente plus matching adjustment

\begin{tabular}{|l|r|l|r|}
\hline \multicolumn{2}{|c|}{ Activa } & \multicolumn{2}{c|}{ Passiva } \\
\hline Staatsobligaties & 100 & Eigen vermogen & 47 \\
\hline Ondernemingsobligaties & 40 & Verzekeringsverplichtingen $(4,8 \%)$ & 93 \\
\hline Balanstotaal & 140 & Balanstotaal & 140 \\
\hline
\end{tabular}

\section{Tabel 9 Marktwaardebalans op $\mathbf{t}=1 \mathrm{bij}$ waardering tegen risicovrije} rente plus matching adjustment

\begin{tabular}{|lr|r|l|r|}
\hline \multicolumn{2}{|c|}{ Activa } & \multicolumn{2}{c|}{ Passiva } \\
\hline Staatsobligaties & 44 & Eigen vermogen & 21 \\
\hline Ondernemingsobligaties & 40 & Verzekeringsverplichtingen (9\%) $\downarrow$ & 63 \\
\hline Balanstotaal & 84 & Balanstotaal & 84 \\
\hline
\end{tabular}

\subsection{Hold-to-maturity-perspectief}

Het "hold-to-maturity"-perspectief redeneert meer vanuit de activazijde van een balans. Een verzekeraar met langetermijnverplichtingen kan een additionele spread verdienen op zijn activa ter dekking van de verzekeringsverplichtingen, genaamd de illiquiditeitsspread, door het aanhouden van de obligaties tot het einde van de looptijd (Barrie+Hibbert, 2009; Wütrich, 2011). Bij het aanhouden tot het einde van de looptijd is de verzekeraar immers uitsluitend nog gevoelig voor het kredietrisico. Dit perspectief neemt tevens aan dat verzekeraars minder gevoelig zijn voor kortetermijnvolatiliteit in de spreads op obligaties.

Uiteindelijk heeft de EG ervoor gekozen om het holdto-maturity-perspectief te incorporeren in Solvency II bij de waardering van langetermijngaranties. De valuation mismatch wordt verkleind door een deel van de spread op de activa te betrekken bij de waardering van de verzekeringsverplichtingen. De activa worden gewaardeerd tegen het effectief rendement, zijnde de risicovrije rente en de volledige spread en de passiva worden gewaardeerd tegen de risico vrije rente met daaraan een activa-afhankelijke illiquiditeitsspread toegevoegd. Het hold-to-maturity-perspectief komt tot uiting in twee maatregelen van de EG, (1) de matching adjustment, en de (2) volatility adjustment (EIOPA, 2013; EG, 2013, art. 77). Beide maatregelen betreffen het toevoe- gen van enige spread aan de rente die gebruikt wordt voor de waardering van verzekeringsverplichtingen.

\subsubsection{Matching adjustment}

De matching adjustment kan uitsluitend toegepast worden op verzekeringsportefeuilles die separaat beheerd worden en waarvan de kasstromen van de investeringen min of meer overeenkomen met de kasstromen van de verplichtingen. De portefeuille moet "cash-flow matched" zijn, zoals in het voorbeeld waar alle kasstromen aan het einde van jaar 10 vallen.

Vervolgens wordt de matching adjustment in twee stappen berekend. Ten eerste wordt de spread van de obligaties opgedeeld in twee componenten (Hull, 2009, p. 495-498):

1. spread die kan worden toegerekend aan kredietrisico; en

2. overige spread, min of meer gelijk aan het deel dat kan worden toegerekend aan liquiditeitsrisico.

Het deel dat wordt toegerekend aan kredietrisico is minimaal gelijk aan $30 \%$ van de gemiddelde historische spread op staatsobligaties en 35\% van de gemiddelde historische spread op ondernemingsobligaties (tabel 7). Ten tweede wordt de volledige "overige spread" toegevoegd aan de rente voor de waardering van de verzekeringsverplichtingen, in dit voorbeeld $6 \%$. De verzekeringsverplichtingen worden derhalve verdisconteerd tegen een effectief rendement van 9\%, zijnde de risicovrije rente van $3 \%$ met daaraan de matching adjustment van $6 \%$ toegevoegd. De waardering van de verzekeringsverplichtingen conform de matching adjustment-methodiek leidt tot een reële waarde van 63 euro (tabel 9).

De waardering van de verzekeringsverplichtingen is in lijn met de waardering van de beleggingen in de portefeuille. De matching adjustment wordt portefeuillespecifiek bepaald. Als gevolg van de matching adjustment wordt het economisch verlies op de beleggingen deels gedempt door het toekennen van een lagere waarde aan de verzekeringsverplichtingen. Het eigen vermogen op de marktwaardebalans is daardoor nog positief. De daling van het eigen vermogen van 47 euro op $t=0$ naar 21 euro op $t=1$ bevat tevens het gestegen kredietrisico op de Italiaanse staatsobligaties (tabel 8 en 9). Zonder enige restricties is het nadeel van deze maatregel dat een verzekeraar zijn solvabiliteitspositie kan verbeteren door het aanschaffen van kwalitatief slechtere obligaties. Dit kan bijvoorbeeld worden ingeperkt door het instellen van minimale vereisten aan de kredietkwaliteit van de portefeuille.

\subsubsection{Volatility adjustment}

De matching adjustment kan uitsluitend worden toegepast op portefeuilles die "cash-flow matched" zijn. In de praktijk is dat niet vaak het geval. De EG heeft 
om deze reden een tweede maatregel geïncorporeerd voor verzekeringsportefeuilles die niet "cash-flow matched" zijn, de volatility adjustment. De volatility adjustment is een beperkte versie van de matching adjustment met drie essentiële verschillen:

1. De volatility adjustment wordt berekend aan de hand van een referentieportefeuille waarin een gemiddelde verzekeringsmaatschappij investeert. Deze maatregel is dus niet portefeuille-specifiek zoals de matching adjustment en kan leiden tot instabiele solvabiliteitscijfers als de eigen beleggingsportefeuille significant afwijkt van de referentieportefeuille.

2. De volatility adjustment kent twee componenten: (1) een Eurozone toevoeging, en (2) een landspecifieke toevoeging. De landspecifieke toevoeging wordt uitsluitend aan de rente ter waardering van de verzekeringsverplichtingen toegevoegd in het geval dat de spreads in de Eurzone significant verschillen, zoals tijdens de Eurocrisis (figuur 4).

3. De overige spread die aan de rente ter waardering van de verzekeringsverplichtingen mag worden toegevoegd is beperkt tot $65 \%$.

Voor de verdere uitwerking van het voorbeeld wordt aangenomen dat de "referentieportefeuille" gelijk is aan de beleggingsportefeuille waarin we investeren. Het enige verschil met de matching adjustment is daarmee dat slechts $65 \%$ van de overige spread kan worden toegevoegd aan de rente ter waardering van de verzekeringsverplichtingen. De verzekeringsverplichtingen worden derhalve verdisconteerd tegen een effectief rendement van $7 \%$, zijnde de risicovrije rente van $3 \%$ plus de volatility adjustment van $4 \%$ (65\% van de $6 \%$ overige spread). De waardering van de verzekeringsverplichtingen conform de volatility adjustment methodiek leidt tot een reële waarde van 75 euro (tabel 11).

De waardering van de verzekeringsverplichtingen is deels in lijn met de waardering van de beleggingen in de portefeuille. Als gevolg van de volatility adjustment wordt het economisch verlies op de beleggingen deels gedempt door het toekennen van een lagere waarde aan de verzekeringsverplichtingen (tabel 10 en 11). Alleen in mindere mate als bij de matching adjustment.

\subsection{Ultimate Forward Rate}

De vorenstaande maatregelen hebben beide betrekking op het korte einde van de rentecurve (korter dan 20 jaar), waarvoor afdoende liquide financiële instrumenten beschikbaar zijn. Langetermijngaranties kunnen echter over een veel langere periode van kracht zijn dan 20 jaar. Voor deze langere looptijden zijn op een gegeven moment niet meer afdoende financiële instrumenten beschikbaar die kunnen dienen als input voor de bepaling van de rente ter waardering van verzekeringsverplichtingen. In het geval van een pensioen kunnen sommige kasstromen 40 jaar of meer in de toekomst

\section{Tabel 10 Marktwaardebalans op $\mathbf{t}=\mathbf{0}$ bij waardering tegen risicovrije rente plus volatility adjustment}

\begin{tabular}{|l|c|l|c|}
\hline \multicolumn{2}{|c|}{ Activa } & \multicolumn{2}{c|}{ Passiva } \\
\hline Staatsobligaties & 100 & Eigen vermogen & 45 \\
\hline Ondernemingsobligaties & 40 & Verzekeringsverplichtingen $(4,5 \%)$ & 95 \\
\hline Balanstotaal & 140 & Balanstotaal & 140 \\
\hline
\end{tabular}

\section{Tabel 11 Marktwaardebalans op $\mathrm{t}=1 \mathrm{bij}$ waardering tegen risicovrije rente plus volatility adjustment}

\begin{tabular}{|lc|c|l|c|}
\hline \multicolumn{2}{|c|}{ Activa } & \multicolumn{2}{c|}{ Passiva } \\
\hline Staatsobligaties & 44 & Eigen vermogen & 9 \\
\hline Ondernemingsobligaties & 40 & Verzekeringsverplichtingen $(7 \%) \downarrow$ & 75 \\
\hline Balanstotaal & 84 & Balanstotaal & 84 \\
\hline
\end{tabular}

liggen. Om volatiliteit in de waardering van zulke langetermijngaranties te voorkomen heeft de EG een additionele maatregel opgenomen in Solvency II die betrekking heeft op het lange einde van de rentecurve (vanaf 20 jaar), de Ultimate Forward Rate (Smith en Wilson, 2001). Deze maatregel fixeert de langetermijnforwardrente op 4,2\% voor de Eurozone (EG, 2013, art. 77). In het solvabiliteitsraamwerk wordt de eerste 20 jaar van de rentecurve bepaald aan de hand van liquide marktinstrumenten. Daarna convergeert de forwardrente in 40 jaar naar deze theoretische Ultimate Forward Rate van 4,2\%.

In deze paragraaf heb ik vanuit zowel een verplichtingen-als een hold-to-maturity-perspectief beargumenteerd waarom het niet te rechtvaardigen is dat alle economische veranderingen tot uiting komen in de solvabiliteitscijfers van verzekeraars. Namelijk omdat verzekeraars minder gevoelig zijn voor kortetermijnvolatiliteit in de spreads op obligaties vanwege hun langetermijninvesteringshorizon.

De EG is tevens van mening dat deze kortetermijnvolatiliteit niet gewenst is en heeft daarom drie dempende maatregelen betreffende langetermijngaranties aan het solvabiliteitsraamwerk toegevoegd, die in deze paragraaf zijn uiteengezet: (1) de matching adjustment, (2) de volatility adjustment, en (3) de ultimate forward rate. In de volgende paragraaf wordt een nadere reflectie op deze maatregelen gegeven.

\section{Reflectie op de maatregelen}

Het hebben van gedegen toezichtsregels voor verzekeraars is van belang voor het functioneren van ons financieel systeem. Dergelijke toezichtsregels beschermen het vermogen van de polishouders en trachten te voorkomen dat het vertrouwen in de financiële sector ondermijnd wordt. De solvabiliteitscijfers die volgen 
uit de toezichtregels worden altijd significant beïnvloed door de voorschreven rentecurve voor de waardering van de verzekeringsverplichtingen.

De EG heeft ervoor gekozen om een drietal maatregelen betreffende de rentecurve in het toezichtregels op te nemen, zijnde de matching adjustment, de volatility adjustment, en de ultimate forward rate. Zonder deze maatregelen zou het eigen vermogen op de marktwaardebalans zeer volatiel zijn in de tijd, terwijl een verzekeraar gezien haar langetermijninvesteringshorizon slechts beperkt gevoelig is voor kortetermijnfluctuaties in de economie. De maatregelen voorkomen naar mijn mening dat een (te) lage rentecurve gebruikt moet worden voor de waardering van de verzekeringsverplichtingen, welke niet in lijn is met de door de verzekeraar gelopen risico's.

De gevoerde producten in de verzekeringsmarkt alsmede de financiering van verzekeraars zouden naar mijn mening beïnvloed worden indien de beschreven maatregelen achterwege zouden blijven. Met betrekking tot de gevoerde producten zou ik verwachten dat verzekeraars terughoudender worden met het verstrekken van langetermijngaranties, bijvoorbeeld voor de pensioenvoorziening. De politiek moet afwegen of dat gewenst is voor ons sociaal systeem. Met betrekking tot de financiering zou ik verwachten dat het vereist rendement voor verzekeraars omhoog gaat. $Z o$ is bekend vanuit dat financieringsleer dat volatiliteit een proxy is voor het risico van een investering (Markowitz, 1952) en vanuit financial accounting theory dat er relaties bestaan tussen gepubliceerde informatie en het gedrag van investeerders (Deegan \& Unerman, 2011). Het zou derhalve zo kunnen zijn dat de kortetermijnvolatiliteit in de solvabiliteitspositie wordt meegenomen in de besluitvorming van investeerders en de rendementseisen die daaruit volgen. Investeerders in verzekeraars zouden in dit geval onterecht een hoger rendement eisen.

Deze mening druist in tegen de stroming die vindt dat garanties uitsluitend gewaardeerd dienen te worden tegen de risicovrije rente (Keller, 2010; Wütrich, 2011). Zij zien maatregelen als de matching adjustment, de volatility adjustment, en de ultimate forward rate als verstoring van puur economisch waarderen. Dit betekent niet dat dit uitgangspunt niet de basis is van andere solvabiliteitsraamwerken. Zo zijn bijvoorbeeld de solvabiliteitsregels voor de Nederlandse pensioenfondsen meer gestoeld op deze gedachte. Als deze solvabiliteitsregels niet vanuit dit perspectief waren vastgesteld, hadden in sommige gevallen de pensioenfondsen er qua solvabiliteit anders voorgestaan. Ter verduidelijking, het vorenstaande betekent niet dat ik vind dat waardering tegen de risicovrije rente niet zou moeten worden betrokken in de interne sturing van een verzekeraar. De complexiteit van een verzekeraar is niet in één getal te vatten en derhalve vind ik het van belang dat meerdere rentecurves worden gebruikt voor interne sturingsdoeleinden.

\section{Conclusie}

Het nieuwe solvabiliteitsraamwerk voor Europese verzekeraars stelt marktwaarden en risico's centraal. De vraag is dan wat de reële waarde van de verzekeringsverplichtingen is en dan met name voor de langetermijngaranties. Een beurskoers is niet beschikbaar voor verzekeringsverplichtingen en daardoor dient de reële waarde vastgesteld te worden aan de hand van een waarderingsmodel waarbij de gebruikte rentecurve één van de belangrijkste aannames is. Moet de rentecurve uitsluitend een risicovrij rendement representeren of niet? In dit artikel heb ik inzichtelijk gemaakt dat de solvabiliteitscijfers van verzekeraars zeer volatiel worden in het geval dat bij de waardering van de verzekeringsverplichtingen uitsluitend uitgegaan wordt van een risicovrij rendement. Alle economische veranderingen komen dan direct en volledig tot uiting in de solvabiliteitscijfers van verzekeraars, waarbij kortetermijnvolatiliteit in de spreads op obligaties significante gevolgen kan hebben voor de solvabiliteitspositie van verzekeraars. Dit was het uitgangspunt van het voorgestelde toezichtskader.

Vanuit zowel een verplichtingen-als een hold-to-maturityperspectief heb ik beargumenteerd waarom het niet te rechtvaardigen is dat alle economische veranderingen tot uiting komen in de solvabiliteitscijfers van verzekeraars. Namelijk omdat verzekeraars beperkt gevoelig zijn voor kortetermijnvolatiliteit in de spreads op obligaties gezien hun langetermijninvesteringshorizon. De EG is tevens van mening dat dit effect niet gewenst is en heeft daarom drie dempende maatregelen aan het solvabiliteitsraamwerk toegevoegd.

Twee maatregelen hebben betrekking op het korte einde van de rentecurve (korter dan 20 jaar) zijnde (1) de matching adjustment en (2) de volatility adjustment. Deze maatregelen bewerkstelligen dat de waardering van de verzekeringsverplichtingen meer in lijn wordt gebracht met de waardering van de beleggingen. Een economisch verlies op de beleggingen wordt dan deels gedempt door het toekennen van een lagere waarde aan de verzekeringsverplichtingen.

De laatste maatregel, de Ultimate Forward Rate, heeft betrekking op het lange einde van de rentecurve (20 jaar en langer). Om volatiliteit in de waardering van langetermijngaranties te voorkomen heeft de EG ervoor gekozen om de langetermijnforwardrente te fixeren op $4,2 \%$ (EG 2013). In het solvabiliteitsraamwerk wordt aangenomen dat er voor de eerste 20 jaren afdoende liquide instrumenten zijn ten behoeve van de rentebepaling. Daarna convergeert de forwardrente in 40 jaar naar deze gefixeerde Ultimate Forward Rate van 4,2\%. Naar mijn mening zijn de genomen maatregelen van be- 
lang voor het functioneren van ons economisch systeem. De solvabiliteitscijfers van verzekeraars reflecteren anders alle kortetermijnfluctuaties in de economie, terwijl verzekeraars daar slechts ten dele gevoelig voor zijn. Zonder deze maatregelen verwacht ik dat verzekeraars minder bereid zijn om langetermijngaranties te verstrekken vanwege de anders volatiele solvabiliteitspositie. Bovendien is het niet uit te sluiten dat deze volatiliteit resulteert in hogere rendementseisen van investeerders.
Deze mening wijkt af van degenen die vinden dat garanties immer tegen een risicovrij rendement moeten worden gewaardeerd (Keller, 2010; Wütrich, 2011)..

P. van Ammelrooij MSc RA AAG is werkzaam in de afdeling Group Actuarial - Life and Health van Allianz SE. Dit artikel is op persoonlijke titel geschreven.

\section{Noten}

Het voorgestelde toezichtskader betreft het kader dat de EG begin 2013 voor ogen had, d.w.z. voor enige aanpassing.
Kredietrisico op Italiaanse staatsobligaties is verondersteld op $0 \%$ op $t=0$.
Ter vereenvouding van het voorbeeld zijn alle economische schokken instantaan verantwoord op de marktwaardebalans ( $t=1)$, ofwel zonder rekening te houden met tijdseffecten.

\section{Literatuur}

- Actuarieel Genootschap en Actuarieel Instituut (AG\&Al) (2009), Principes voor de rentetermijnstructuur. "Dé juist curve bestaat niet". Geraadpleegd op www.ag-ai.nl/.

- Allen, F., \& Carletti, E. (2008). Mark-to-market accounting and liquility pricing. Journal of Accounting and Economics, 45(2+3), 358378.

- Barrie+Hibbert (company) (2009), Estimation of the liquidity premium in corporate bond vields, Presentation by John Hibbert. Geraadpleegd op http://www.actuaries.org.hk/upload/File/ET090513.pdf.

- Deegan, C., \& Unerman, J. (2011). Financial Accounting Theory. McGraw Hill Book Company.

- European Insurance and Occupational Pensions Authority (EIOPA) (2013). Technical Findings on the Long-Term Guarantee Assessment. Geraadpleegd op https://eiopa.europa. eu/fileadmin/tx_dam/files/consultations/QIS/ Preparatory_forthcoming_assessments/final/ outcome/EIOPA_LTGA_Report_14_ June_2013_01.pdf.

- Europese Economische Gemeenschap (EEG) (1973). Eerste Richtlijn 73/239/EEG van de Raad van 24 juli 1973 tot coördinatie van de wettelijke en bestuursrechtelijke bepalingen betreffende de toegang tot het directe verzekeringsbedrijf, met uitzondering van de levensverzekeringsbranche, en de uitoefening daarvan. Geraadpleegd op http://eur-lex.europa.eu/LexUriServ/LexUriServ.do?uri=CELEX:3 1973LO239:NL:HTML.

- Europese Economische Gemeenschap (EEG) (1979). De Eerste Richtliin 79/267/EEG van de Raad van 5 maart 1979 tot coördinatie van de wettelijke en bestuursrechtelijke bepalingen betreffende de toegang tot het directe levensverzekeringsbedrijf, en de uitoefening daarvan. Geraadpleegd op http://eur-lex.europa.eu/LexUriServ/LexUriServ.do?uri=CELEX:3 1979LO267:NL:HTML.

- Europese Gemeenschap (EG), 2002, Richtliin 2002/83/EG van het Europees Parlement en de Raad van 5 november 2002 betreffende levensverzekering. Geraadpleegd op http:// eur-lex.europa.eu/LexUriServ/LexUriServ.do?u ri=CONSLEG:2002L0083:20080320:NL:PDF.

- Europese Gemeenschap (EG) (2009). Richtlijn 2009/138/EG van het Europees Parlement en de Raad van 25 november 2009 betreffende de toegang tot en uitoefening van het verzekerings- en het herverzekeringsbedrijf (Solvabiliteit II). Geraadpleegd op http://eurlex.europa.eu/LexUriServ/LexUriServ.do?uri=
0J:L:2009:335:0001:0155:NL:PDF.

- Europese Gemeenschap (EG) (2013). Aanpassing: Concept Richtlijn van het Europees Parlement en de Raad van 25 november 2009 betreffende de toegang tot en uitoefening van het verzekerings- en het herverzekeringsbedrijf (Solvabiliteit Il, Omnibus II).

- Hull, J.C. (2009). Options, futures, and other derivatives. $7^{\text {th }}$ edition. Pearson Prentice Hall.

- International Accounting Standards Board (IASB) (2011). IFRS 13 Fair Value Measurement.

- Keller, P. (2010). Some comments on the illiquidity premium. Swiss Association of Actuaries. Geraadpleegd op www.actuaries.ch.

- Krens, F. (2003). Het begrip reële waarde. Maandblad voor Accountancy en Bedriffseconomie, 77(9), 371-378.

- Markowitz, H.M. (1952). Portfolio selection. The Journal of Finance, 7(1), 77-91.

- Smith, A., \& Wilson, T. (2001). Fitting yield curves with long term constraints. Research Notes, Bacon and Woodrow.

- Wütrich, M.V. (2011). An academic view on the illiquidity premium and market-consistent valuation in insurance. European Actuarial Journal, 1(1), 93-105. 